\title{
DUKUNGAN TENAGA KESEHATAN TERHADAP PELAKSANAAN INISIASI MENYUSU DINI
}

\author{
Nidya Aryani ${ }^{1}$ \\ 1Prodi Kebidanan Sekolah Tinggi Ilmu Kesehatan Panca Bhakti \\ email : nidya.aryani.75@gmail.com
}

\begin{abstract}
Background : Early Breastfeeding Initiation (IMD) is a process of allowing a baby with its own instincts to breastfeed immediately within one hour after birth, together with contact between the baby"s skin and the mother"s skin. Support of health workers plays a role in implementation of IMD but there are still many health workers who do not support or motivate and do not facilitate the implementation of IMD during the delivery process and the commitment of health workers to implement IMD in newborns is not optimal.

Purpose : To determine the relationship of health support with the implementation of IMD in maternity in the Widwife Independent Practice (PMB) Wirahayu, S.ST.

Method: This type of research used in this research is quantitative with cross sectional research design. The population of this study was all spontaneous post partum mothers treated at PMB Wirahayu, S.ST Bandar Lampung during March 2018 as many as 46 people. The research sample uses accidental sampling method where the sample taken is the entire population. Retrieval of data using a questionnaire. Data analysis using bivariate analysis with chi square.

Result: The statistical test result with chi square obtained $p$-value $=0,000$, which means ther is a relationship between the support of health workers with Early Breastfeeding Initiation (IMD).

Conclusion : There is a correlation between the support of health workers for the implementation of IMD in maternity in PMB Wirahayu, S.ST in 2018 with $p$-value $=0,000$ and $O R=23,333$

Suggestion The Indonesian Midwives Association of Lampung Province to more often hold training or seminars related to IMD or ASI for health workers, especially midwives. Health workers are also advised to focus more on providing counseling during pregnancy examinations by advising mothers to routinely carry out examinations and be diligent in seeking information about IMD and ASI both from the KIA book or from the media.
\end{abstract}

Keywords : Support of Health Workers, Early Breastfeeding Initiation, Mother of Birth

\section{ABSTRAK}

Latar belakang : Inisiasi Menyusu Dini (IMD) merupakan suatu proses membiarkan bayi dengan nalurinya sendiri untuk menyusu segera dalam satu jam setelah lahir, bersamaan dengan kontak antar kulit bayi dengan kulit ibu. Dukungan tenaga kesehatan berperan dalam pelaksanaan IMD namun masih banyak ditemukan tenaga kesehatan yang kurang mendukung atau memotivasi dan tidak memfasilitasi pelaksanaan IMD pada saat proses persalinan serta belum optimalnya komitmen dari tenaga kesehatan untuk menerapkan IMD pada bayi baru lahir.

Tujuan penelitian : Untuk mengetahui hubungan dukungan tenaga kesehatan dengan pelaksanaan IMD pada ibu bersalin di Praktik Mandiri Bidan (PMB) Wirahayu, S.ST.

Metode : Jenis penelitian yang digunakan dalam penelitian ini adalah Kuantitatif dengan desain penelitian Cross Sectional. Populasi penelitian ini adalah seluruh ibu post partum spontan di PMB Wirahayu, S.ST Bandar Lampung selama bulan Maret 2018 sebanyak 46 orang. Sampel penelitian menggunakan metode accidental sampling dimana sample yang diambil adalah seluruh populasi. Pengambilan data menggunakan kuesioner. Analisis data menggunakan analisis bivariat dengan (chi square).

Hasil penelitian : Hasil uji statistik dengan chi square diperoleh $p$-value $=0,000$ yang berarti ada hubungan dukungan tenaga kesehatan dengan Inisiasi Menyusu Dini (IMD).

Kesimpulan : Ada hubungan dukungan tenaga kesehatan terhadap pelaksanaan IMD pada ibu bersalin di PMB Wirahayu, S.ST tahun 2018 dengan $p$-value $=0,000$ dan $O R=23,333$.

Saran Ikatan Bidan Indonesia Provinsi lampung untuk lebih sering mengadakan pelatihan ataupun seminar yang berkaitan dengan IMD atau ASI bagi tenaga kesehatan khususnya Bidan. Tenaga kesehatan juga disarankan untuk lebih fokus memberikan konseling pada saat pemeriksaan kehamilan dengan menyarankan ibu untuk rutin melakukan pemeriksaan dan rajin mencari informasi mengenai IMD dan ASI baik dari buku KIA ataupun dari media. 
Kata Kunci : Dukungan Tenaga Kesehatan, Inisiasi Menyusu Dini, Ibu Bersalin

\section{PENDAHULUAN}

Indonesia masih mengalami berbagai permasalahan terkait rendahnya derajat kesehatan masyarakat, salah satunya adalah Angka Kematian Bayi (AKB) tidak mengalami penurunan yang signifikan tahun 2012 dari tahun 2007 yaitu sebesar 19 Angka Kematian Neonatal per 1000 kelahiran hidup dari total 32 AKB per 1000 kelahiran hidup (SDKI, 2012).

Salah satu langkah yang utama dalam mencegah terjadinya kematian bayi neonatal adalah dengan melakukan Inisiasi Menyusu Dini. Inisiasi Menyusu Dini (IMD) merupakan suatu proses membiarkan bayi dengan nalurinya sendiri untuk menyusu segera dalam satu jam setelah lahir, bersamaan dengan kontak antar kulit bayi dengan kulit ibu (Depkes RI, 2008).

IMD memiliki manfaat penting bagi bayi dalam 1 jam setelah melahirkan dimungkinkan bayi mendapat kolostrum yaitu ASI yang pertama kali keluar (berwarna kekuningan) dan mengandung zat gizi mudah cerna, substansi imunoaktif dan faktor pertumbuhan. Kolostrum juga memberikan zat gizi dan perlindungan paling baik bagi bayi dalam menjaga ketahanan tubuh bayi terhadap infeksi kuman dan bakteri sehingga meningkatkan kekebalan tubuh sang bayi. Sedangkan manfaat penting IMD bagi ibu dapat mengurangi resiko perdarahan post partum dan mengurangi infeksi setelah melahirkan karena isapan pada putting susu dalam waktu 30 menit sampai 1 jam setelah lahir akan mempercepat lahirnya plasenta melalui pelepasan oksitosin (Keller.Helen, 2002).

Kebijakan UNICEF merekomendasikan IMD sebagai tindakan "penyelamatan kehidupan", karena berdasarkan penelitian di Ghana IMD dapat menyelamatkan $22 \%$ bayi yang meninggal jika IMD dilakukan pada satu jam setelah melahirkan (UNICEF, 2007). IMD juga memberikan pengaruh nyata terhadap keberhasilan ASI Eksklusif dimana ibu memiliki peluang 8 kali lebih besar untuk keberhasilan dalam pemberian ASI Eksklusif dibanding ibu yang tidak melakukan IMD (Fikawati, 2010).

Menurut WHO (2016) persentase Inisiasi Menyusu Dini di Indonesia pada tahun 2012 sebesar $53,7 \%$ dan Propinsi Lampung sebesar 45,8\%. Menurut data RISKESDAS (2013) persentase Inisiasi Menyusu Dini pada anak umur 0-23 bulan di Indonesia pada tahun 2013 sebesar 34,5\%. Persentase tertinggi di Propinsi Nusa Tenggara
Barat (NTB) sebesar 52,9\% dan persentase terendah di Propinsi Papua Barat sebesar 21,7\%. Sedangkan Propinsi Lampung termasuk dalam persentase rendah yaitu sebesar 23\% (Kemenkes, 2014).

Dukungan tenaga kesehatan berperan dalam pelaksanaan IMD. Menurut Peraturan Menteri Negara Pemberdayaan Perempuan dan Perlindungan Anak Republik Indonesia nomor 03 (2010) di beberapa fasilitas pelayanan kesehatan masih didapatkan tenaga kesehatannya belum mendapatkan ketrampilan untuk ibu hamil dan menyusui berupa komunikasi, informasi dan edukasi (KIE) tentang tehnik pemberian ASI yang baik dan benar.

Penelitian yang dilakukan oleh Fika dan Syafiq (2003) bahwa keberhasilan IMD terletak pada dukungan tenaga kesehatan dalam hal ini penolong persalinan dimana pada 30 menit pertama setelah bayi lahir peran penolong persalinan sangat dominan. Bila ibu difasilitasi untuk memeluk bayinya, maka interaksi antara ibu dan bayi akan terjadi sehingga IMD dapat terlaksana dengan baik. Penelitian yang dilakukan oleh Novianti dan Anisa (2013) bahwa dukungan tenaga kesehatan terlihat dari upaya tenaga kesehatan untuk menginformasikan tata laksana dan manfaat IMD, mendampingi ibu saat proses IMD dilakukan, serta adanya komitmen tinggi dan sikap positif tenaga kesehatan ditunjang dengan peraturan yang jelas mengenai praktik IMD. Penelitian Sri Lestariningsih (2016) bahwa sebagian besar persalinan tidak melakukan IMD dikarenakan tidak mendapat dukungan dari tenaga kesehatan pada saat pemeriksaan kehamilan dan sebelum bersalin. Hal ini disebabkan karena tidak adanya SOP pelaksanaan IMD di Ruang Bersalin RS sehingga pelaksanaan IMD kurang mendapat perhatian dari tenaga kesehatan. Kurangnya dukungan dan belum optimalnya komitmen dari tenaga kesehatan serta tidak memfasilitasi pelaksanaan IMD pada saat proses persalinan akan menghambat pelaksanaan IMD pada bayi baru lahir.

Dari hasil pra survey yang dilakukan di PMB Wirahayu, S.ST pada bulan Januari 2018 terdapat 37 orang bersalin dan berdasarkan hasil kuesioner diperoleh yang tidak melakukan IMD sebanyak 17 orang $(46 \%)$, hal ini dikarenakan ibu masih belum faham manfaat Inisiasi Menyusu Dini. Selain itu diduga bahwa kurangnya informasi yang diperoleh ibu dari tenaga kesehatan mengenai Inisiasi 
Menyusu Dini selama melakukan pemeriksaan kehamilan.

Berdasarkan uraian masalah diatas dan mengingat pentingnya pelaksanaan IMD maka peneliti tertarik untuk melakukan penelitian tentang "Hubungan Dukungan Tenaga Kesehatan dengan Inisiasi Menyusu Dini di Praktik Bidan Mandiri Wirahayu, S.ST Bandar Lampung"

\section{METODE PENELITIAN}

Jenis penelitian yang digunakan dalam penelitian ini adalah Kuantitatif dengan desain penelitian Cross Sectional. Variabel Dependent dari penelitian ini adalah Inisiasi Menyusu Dini dan variabel Independentnya dalah dukungan tenaga kesehatan. Populasi penelitian ini adalah seluruh ibu post partum spontan bulan Maret 2018 yang dirawat di Praktik Mandiri Bidan Wirahayu, S.ST Bandar Lampung sebanyak 46 orang. Sampel penelitian menggunakan metode accidental sampling dimana sample yang diambil adalah seluruh populasi. Pengambilan data menggunakan kuesioner. Analisis data menggunakan analisis bivariat dengan (chi square).

\section{HASIL PENELITIAN}

\section{Analisis Univariat}

Berdasarkan tabel 1 menunjukkan bahwa yang melakukan Inisiasi Menyusu Dini sebesar $65,2 \%$ dan yang tidak melakukan Inisiasi Menyusu Dini sebesar $34,8 \%$.
Tabel 1.

Distribusi Frekuensi Inisiasi Menyusu Dini dan Dukungan Tenaga Kesehatan terhadap Ibu Nifas

\begin{tabular}{lcc}
\hline \multicolumn{1}{c}{ Variabel } & Jumlah & Persentase \\
\hline Inisiasi Menyusu Dini & & \\
Melakukan & 30 & 65,2 \\
Tidak Melakukan & 16 & 34,8 \\
Dukungan Tenaga & & \\
Kesehatan & & \\
Mendukung & 34 & 73,9 \\
Tidak mendukung & 12 & 26,1 \\
\hline
\end{tabular}

\section{Analisis Bivariat}

Berdasarkan Tabel 2 menunjukkan bahwa tenaga kesehatan yang tidak mendukung dan tidak melakukan IMD sebesar $83,3 \%$ dan tenaga kesehatan yang tidak mendukung dan melakukan IMD sebesar $16,7 \%$, sedangkan tenaga kesehatan yang mendukung dan tidak melakukan IMD sebesar $17,6 \%$ dan tenaga kesehatan yang mendukung dan melakukan IMD sebesar 82,4\%.

Hasil uji statistik dengan chi square diperoleh $p$-value $=0,000(p$-value $<a=0,05)$ yang berarti ada hubungan dukungan tenaga kesehatan dengan Inisiasi Menyusu Dini, dan diperoleh OR = 23,333.

Tabel 2.

Hubungan Dukungan Tenaga Kesehatan dengan Inisiasi Menyusu Dini

\begin{tabular}{|c|c|c|c|c|c|c|c|c|}
\hline \multirow{3}{*}{$\begin{array}{l}\text { Dukungan } \\
\text { Tenaga Kes }\end{array}$} & \multicolumn{6}{|c|}{ Inisiasi Menyusu Dini } & \multirow{3}{*}{$\mathrm{p}$-value } & \multirow{3}{*}{$\begin{array}{c}\text { OR } \\
95 \% \mathrm{Cl}\end{array}$} \\
\hline & \multicolumn{2}{|c|}{ Tdak Melakukan } & \multicolumn{2}{|c|}{ Melakukan } & \multicolumn{2}{|c|}{ Total } & & \\
\hline & $\mathbf{N}$ & $\%$ & N & $\%$ & N & $\%$ & & \\
\hline Tidak Mendukung & 10 & 83,3 & 2 & 16,7 & 12 & 100 & \multirow{3}{*}{0,000} & \multirow{3}{*}{$\begin{array}{c}23,333 \\
(4,032-135,035)\end{array}$} \\
\hline Mendukung & 6 & 17,6 & 28 & 82,4 & 34 & 100 & & \\
\hline Jumlah & 16 & & 30 & & 46 & & & \\
\hline
\end{tabular}

\section{PEMBAHASAN}

Analisis Univariat

Inisiasi Menyusu Dini

Berdasarkan tabel 1 menunjukkan bahwa yang berhasil melakukan IMD di PMB Wirahayu, S.ST sebesar $65,2 \%$ dan yang tidak melakukan IMD sebesar $34,8 \%$.

Persentasi tersebut lebih tinggi bila dibandingkan dengan persentase Inisiasi Menyusu Dini di Indonesia, menurut data RISKESDAS pada tahun 2013 sebesar 34,5\% dan Propinsi Lampung sebesar 23\% (Kemenkes, 2014).
Manfaat penting Inisiasi Menyusu Dini dalam 1 jam setelah melahirkan dimungkinkan bayi mendapat kolostrum yaitu ASI yang pertama kali keluar (berwarna kekuningan) dan mengandung zat gizi mudah cerna, substansi imunoaktif dan faktor pertumbuhan. Pentingnya melakukan IMD adalah kontak kulit dengan kulit segera setelah lahir dan bayi menyusu sendiri dalam satu jam pertama kehidupan karena dada ibu menghangatkan bayi dengan tepat selama bayi merangkak mencari payudara. Ini akan menurunkan kematian karena hypothermia. Sedangkan manfaat penting IMD pada 
ibu dapat mengurangi resiko perdarahan post partum dan mengurangi infeksi setelah melahirkan karena isapan pada putting susu dalam waktu 30 menit sampai 1 jam setelah lahir akan mempercepat lahirnya plasenta melalui pelepasan oksitosin. Air Susu Ibu di hari pertama belum sebanyak di hari-hari berikutnya, tetapi rangsangan isapan bayi sangat penting untuk kelancaran produksinya (Roesli, 2010).

Pada penelitian ini ibu yang tidak melakukan IMD sebagian besar dikarenakan ibu kurang faham mengenai IMD dan kurangnya informasi yang diberikan tenaga kesehatan pada saat pemeriksaan kehamilan. Selain itu alasan lain disebabkan karena saat proses persalinan tenaga kesehatan tidak memberitahu ibu untuk melakukan IMD. Kemungkinan tenaga kesehatan melakukan pertolongan persalinan sendiri sehingga lupa untuk melakukan IMD dan mendampingi ibu. Sedangkan ada 6 orang ibu yang sudah mendapat informasi mengenai IMD ketika pemeriksaan kehamilan namun tidak melakukan IMD ketika proses persalinan dikarenakan bayi premature, bayi asfiksia dan ibu yang terlalu lelah sehingga tidak memungkinkan dilakukan IMD.

\section{Dukungan Tenaga Kesehatan}

Berdasarkan tabel 1 menunjukkan bahwa tenaga kesehatan yang memberikan dukungan terhadap pelaksanaan IMD sebesar $73,9 \%$ dan yang tidak memberikan dukungan terhadap pelaksanaan IMD sebesar $26,1 \%$.

Tenaga kesehatan merupakan salah satu unsur yang berperan dalam percepatan pembangunan dalam memberikan pelayanan kesehatan. Pelayanan kesehatan dipengaruhi ketersediaan tenaga kesehatan (Depkes, 2009). Pelayanan yang diberikan pada ibu tersebut dapat dilaksanakan pada saat masa kehamilan berupa penyuluhan maupun saat ibu bersalin. Adapun petugas kesehatan yang dimaksudkan adalah dokter dan bidan. Hal ini sesuai Permenkes RI no 512 (2007) yang menyebutkan pelaksanaan praktik dokter dalam upaya pemeliharaan kesehatan, pencegahan penyakit, peningkatan kesehatan, pengobatan penyakit dan pemulihan kesehatan. Dalam hal ini tugas seorang dokter dalam pemeliharaan dan peningkatan kesehatan termasuk memberikan pelayanan yang termasuk didalamnya mensukseskan pemberian ASI yang dimulai dengan pelaksanaan Inisiasi Menyusu Dini.

Dukungan tenaga kesehatan yang diberikan pada pelaksanaan IMD di PMB Wirahayu, S.ST sudah berjalan baik. Konseling pada saat pemeriksaan kehamilan mengenai IMD sudah diberikan kepada ibu maupun suami atau keluarga. Pada saat persalinan tenaga kesehatan juga memberikan dukungan dengan mengingatkan ibu untuk melakukan IMD segera setelah bayi lahir.

\section{Analisis Bivariat}

Hubungan antara Dukungan Tenaga Kesehatan dengan Inisiasi Menyusu Dini

Berdasarkan penelitian diperoleh responden yang melakukan IMD yang mendapat dukungan tenaga kesehatan $82,4 \%$ dan yang tidak melakukan IMD lebih banyak pada yang tidak mendapat dukungan tenaga kesehatan $83,3 \%$. Hasil uji chi square didapatkan nilai $p=0,000$ ( $p$ value $<0,05$ ) yang artinya terdapat hubungan yang bermakna antara dukungan tenaga kesehatan dengan IMD di PMB Wirahayu, S.ST. Kemudian diperoleh OR = 23,333 yang berarti bahwa ibu yang mendapat dukungan tenaga kesehatan akan mempunyai odds (peluang) untuk melakukan IMD 23,333 kali lebih besar dibandingkan ibu yang tidak mendapat dukungan tenaga kesehatan.

Hasil penelitian ini sejalan dengan penelitian yang dilakukan oleh Fika dan Syafiq (2003) bahwa keberhasilan IMD terletak pada dukungan tenaga kesehatan dalam hal ini penolong persalinan dimana pada 30 menit pertama setelah bayi lahir peran penolong persalinan sangat dominan. Bila ibu difasilitasi untuk memeluk bayinya, maka interaksi antara ibu dan bayi akan terjadi sehingga IMD dapat terlaksana dengan baik. Penelitian yang dilakukan oleh Novianti dan Anisa (2013) bahwa dukungan tenaga kesehatan terlihat dari upaya tenaga kesehatan untuk menginformasikan tata laksana dan manfaat IMD, mendampingi ibu saat proses IMD dilakukan, serta adanya komitmen tinggi dan sikap positif tenaga kesehatan ditunjang dengan peraturan yang jelas mengenai praktik IMD. Penelitian Sri Lestariningsih (2016) bahwa sebagian besar persalinan tidak melakukan IMD dikarenakan tidak mendapat dukungan dari tenaga kesehatan pada saat pemeriksaan kehamilan dan sebelum bersalin. Hal ini disebabkan karena tidak adanya SOP pelaksanaan IMD di Ruang Bersalin RS sehingga pelaksanaan IMD kurang mendapat perhatian dari tenaga kesehatan. Kurangnya dukungan dan belum optimalnya komitmen dari tenaga kesehatan serta tidak memfasilitasi pelaksanaan IMD pada saat proses persalinan akan menghambat pelaksanaan IMD pada bayi baru lahir.

Pada Kepmenkes RI no 900 (2002) disebutkan bahwa bidan berwenang memberikan pelayanan kebidanan kepada ibu pada masa kehamilan, persalinan, masa nifas yang meliputi penyuluhan dan konseling, pemeriksaan fisik, 
pelayanan masa kehamilan, pertolongan persalinan. Ini menunjukkan bahwa peran bidan sangat besar untuk membantu dalam pelaksanaan IMD.Bagi tenaga Kesehatan khususnya bidan untuk dapat lebih meningkatkan dalam melakukan peyuluhan dan konseling kepada ibu pada saat hamil,bersalin dan menyusui.(Susilawati,2015)

Menurut Peraturan Menteri Negara Pemberdayaan Perempuan dan Perlindungan Anak Republik Indonesia nomor 03 (2010) tentang penerapan sepuluh langkah menuju keberhasilan menyusui pasal 5 disebutkan bahwa "melakukan pelatihan bagi petugas dalam hal pengetahuan dan ketrampilan untuk menerapkan kebijakan tersebut". Petugas kesehatan juga selayaknya "menjelaskan kepada semua ibu hamil tentang manfaat menyusui dan penatalaksanaannya dimulai sejak masa kehamilan, masa lahir sampai umur dua tahun termasuk cara mengatasi kesulitan menyusu".

Berdasarkan beberapa penelitian yang sejalan yang pernah dilakukan dan mengacu pada peraturan pemerintah yang ada mengenai IMD maka ditemukan adanya keterkaitan dan kesesuaian dengan penelitian ini. Dukungan tenaga kesehatan sangat besar perannya dalam membantu pelaksanaan IMD. Tenaga kesehatan yang dimaksudkan dalam penelitian ini adalah Bidan Wirahayu dan tenaga kesehatan yang bekerja pada PMB yang memberikan pelayanan pada ibu saat masa kehamilan maupun saat ibu bersalin yaitu dengan menginformasikan tata laksana dan manfaat IMD, mendampingi ibu saat proses IMD dilakukan. Selain itu adanya komitmen tinggi dan sikap positif tenaga kesehatan ditunjang dengan adanya SOP mengenai IMD merupakan upaya dalam mensukseskan pemberian ASI yang dimulai dengan pelaksanaan IMD.

\section{SIMPULAN}

Berdasarkan hasil penelitian dapat diambil kesimpulan bahwa yang berhasil melakukan IMD sebesar $65,2 \%$ (30 orang) dan dukungan tenaga kesehatan melakukan IMD sebesar $82,4 \%$ (28 orang). Hasil penelitian bivariat diperoleh $\mathrm{p}$-value $=$ 0,000 dan $\mathrm{OR}=23,333$. Artinya ada hubungan antara dukungan tenaga kesehatan terhadap pelaksanaan IMD di PMB Wirahayu, S.ST.

\section{SARAN}

Saran bagi Ikatan Bidan Indonesia Provinsi lampung untuk lebih sering mengadakan pelatihan ataupun seminar yang berkaitan dengan IMD atau ASI bagi tenaga kesehatan khususnya Bidan.
Tenaga kesehatan juga disarankan untuk lebih fokus memberikan konseling pada saat pemeriksaan kehamilan dengan menyarankan ibu untuk rutin melakukan pemeriksaan dan rajin mencari informasi mengenai IMD dan ASI baik dari buku KIA ataupun dari media.

\section{DAFTAR PUSTAKA}

Aprina, Luksfita N, 2015, Faktor-faktor yang Berhubungan dengan Pelaksanaan Inisiasi Menyusu Dini (IMD) di RSIA Mutiara Putri Bandar Lampung, Jurnal Skala Kesehatan Volume 6 No.2 Tahun 2015.

Ariawan I, 1998, Besar dan Metode Sampel pada Penelitian Kesehatan, Jurusan Biostatistik dan Kependudukan, Fakultas Kesehatan Masyarakat, Universitas Indonesia.

Arikunto S, 2013, Prosedur Penelitian Suatu Pendekatan Praktik, Edisi Kelimabelas, Rineka Cipta, Jakarta.

Aryani N, 2017, Faktor-faktor yang Berhubungan dengan Inisiasi Menyusu Dini di Wilayah Kerja Puskesmas Satelit Bandar Lampung, Jurnal Kesehatan Panca Bhakti Volume 6 No 1 (2018).

Departemen Kesehatan RI, 2008, Pesan-pesan tentang Inisiasi Menyusu Dini dan Air Susu Ibu (ASI) Eksklusif untuk Tenaga Kesehatan dan Keluarga Indonesia, Direktorat Bina Gizi Masyarakat, Bhakti Husada, Jakarta.

Dinas Kesehatan Kota Bandar Lampung, 2016, Profil Kesehatan Kota Bandar Lampung, Lampung

Dinas Kesehatan Provinsi Lampung, 2014, Profil Kesehatan Provinsi Lampung Tahun 2014, Lampung

Edmond KM, Zandoh C, Quigley MA, Amenga Etego S, Owusu-Agyei, Kirkwood BR, 2006, Delayed breastfeeding initiation increases risk of neonatal mortality, Pediatrics, 2006;117;380-6

Fikawati S, Syafiq A, Kajian Implementasi dan Kebijakan Air Susu Ibu Eksklusif dan Inisiasi Menyusu Dini di Indonesia, Jurnal Kesehatan Masyarakat Nasional, Volume 14, Nomor 1 , Juni 2010.

Fikawati S, Syafiq A, Karima K, 2015, Gizi Ibu dan Bayi, Edisi Kedua, Raja Grafindo Persada, Jakarta.

Keller, Hellen, 2002, Breastfeeding and Complementary Feeding Practice in Indonesia-Annual Report, Departemen Kesehatan RI, USAID, NSS

Kementerian Kesehatan Republik Indonesia, 2014, Situasi dan Analisis ASI Eksklusif, Jakarta 
Lestariningsih S, Dukungan Tenaga Kesehatan di Ruang Bersalin RSUD Jendral Ahmad Yani Metro terhadap Pelaksanaan Inisiasi Menyusu Dini, Jurnal Kesehatan Metro Sai Wawai Volume 9, No.1 Edisi Juni 2016

Notoatmodjo S, 2012, Metodologi Penelitian Kesehatan, Edisi Revisi, Rineka Cipta, Jakarta.

Novianti, Rizkianti A, Dukungan Tenaga Kesehatan terhadap Pelaksanaan IMD : Studi Kasus di RS Swasta $X$ dan RSUD Y di Jakarta, Jurnal Kesehatan Reproduksi Volume 7, No 22016

RISKESDAS, 2013, Riset Kesehatan Dasar 2013, Badan Penelitian dan Pengembangan Kesehatan Kementrian Kesehatan RI

Riyanto A, 2011, Aplikasi Metodologi Penelitian Kesehatan, Edisi Kedua, Nuha Medika, Yogyakarta.

Roesli U, 2010, Inisiasi Menyusu Dini Plus ASI Eksklusif, Edisi Keempat, Pustaka Bunda, Jakarta.
Sugiyono, 2011, Metode Penelitian Kuantitatif, Kualitatif, dan R\&D, Edisi Ketigabelas, Alfabeta,Bandung

Susilawati, S., \& Maulina, R. (2015). Faktor-Faktor yang Berhubungan dengan Penghambat Pemberian ASI Eksklusif di Wilayah Kerja Posyandu Melati Kecamatan Gedong Tataan Kabupaten Pesawaran Tahun 2014. Jurnal Kebidanan Malahayati, 1(1).

SDKI, 2012, Survey Demografi Kesehatan Indonesia 2012, Badan Kependudukan Keluarga Berencana Nasional, Badan Pusat Statistik, Kementerian Kesehatan

UNICEF, 2007, Breastfeeding Within One Hour of Birth can Reduce Infant Mortalit

WHO, 2016, Global Health Observatory Data Repository 